University of Nebraska - Lincoln

DigitalCommons@University of Nebraska - Lincoln

\title{
Economic analysis of small-scale agricultural digesters in the United States
}

\author{
Katherine $\mathrm{H}$. Klavon \\ University of Maryland \\ Stephanie A. Lansing \\ University of Maryland, slansing@umd.edu \\ Walter Mulbry \\ USDA-ARS Environmental Management and Byproducts Laboratory \\ Andrew R. Moss \\ University of Maryland \\ Gary Felton \\ University of Maryland
}

Follow this and additional works at: https://digitalcommons.unl.edu/usdaarsfacpub

Klavon, Katherine H.; Lansing, Stephanie A.; Mulbry, Walter; Moss, Andrew R.; and Felton, Gary, "Economic analysis of small-scale agricultural digesters in the United States" (2013). Publications from USDA-ARS / UNL Faculty. 1159.

https://digitalcommons.unl.edu/usdaarsfacpub/1159

This Article is brought to you for free and open access by the U.S. Department of Agriculture: Agricultural Research Service, Lincoln, Nebraska at DigitalCommons@University of Nebraska - Lincoln. It has been accepted for inclusion in Publications from USDA-ARS / UNL Faculty by an authorized administrator of DigitalCommons@University of Nebraska - Lincoln. 


\title{
Economic analysis of small-scale agricultural digesters in the United States
}

\author{
Katherine H. Klavon ${ }^{a}$, Stephanie A. Lansing ${ }^{a, *}$, Walter Mulbry ${ }^{b}$, \\ Andrew R. Moss ${ }^{a}$, Gary Felton ${ }^{a}$ \\ ${ }^{a}$ Department of Environmental Science and Technology, Renewable Energy Research Center, University of Maryland, \\ 1445 Ag Engineering Building, College Park, MD 20742, USA \\ ${ }^{\mathrm{b}}$ USDA/ARS Environmental Management and Byproducts Laboratory, Beltsuille, MD 20705, USA
}

\section{A R T I C L E I N F O}

Article history:

Received 5 February 2012

Received in revised form

8 March 2013

Accepted 10 March 2013

Available online 18 April 2013

Keywords:

Anaerobic digestion

Small-scale

Manure

Biogas

Economic analysis

\begin{abstract}
A B S T R A C T
Anaerobic digestion (AD) is an economically viable manure treatment option for large dairies (>500 cows) in the U.S. However, roughly $90 \%$ of U.S. dairies have less than 200 cows, making this technology economically inaccessible to the vast majority of U.S. dairies. While there have been case studies of individual small dairies with anaerobic digesters, there are no comparative studies using cost data from these systems. The objectives of this study were to (1) determine the economic viability of small-scale U.S. digesters using cost data from nine existing 100 to 250-cow dairies and seven theoretical systems and (2) reevaluate the minimum size dairy farm needed for economically feasible $\mathrm{AD}$ in the U.S. Cash flow analysis results showed that total capital costs, capital costs per cow, and net costs per cow generally decreased with increasing herd size in existing systems. Among existing revenue streams, use of digested solids for bedding generated the highest revenue $\left(\$ 100\right.$ cow $^{-1}$ year $^{-1}$ ), followed by biogas use for heating and/or electrical generation ( $\$ 47$ to $\$ 70 \mathrm{cow}^{-1}$ year $^{-1}$ ) and $\mathrm{CO}_{2}$ credits $\left(\$ 7 \mathrm{cow}^{-1}\right.$ year $\left.^{-1}\right)$. No system had a positive cash flow under the assumed conditions ( $8 \%$ discount rate, 20-year term). However, six of the 16 systems had positive cash flows when $50 \%$ cost sharing was included in the analysis. Our results suggest that, with cost sharing, economically viable $A D$ systems are possible on 250-cow dairies. Additional revenue streams, such as tipping fees for food waste, may reduce the minimum size to 100 -cow dairies.
\end{abstract}

(c) 2013 Elsevier Ltd. All rights reserved.

\section{Introduction}

Anaerobic digestion is a microbial-mediated process in which methanogenic microorganisms utilize organic matter, carbon dioxide, and hydrogen to produce methane, resulting in the creation of renewable energy and decreases in greenhouse gas emissions, organic pollutants, pathogens, and odor [1,2-8]. Agricultural digesters utilizing this process were first widely constructed in the United States during the 1970s [1,9].
Unfortunately, poor economic viability and technical flaws led to a $60 \%$ failure rate of these systems [10]. Through improved designs, the world is currently seeing a revitalization of anaerobic digestion technology with over 30 million manurebased digesters operating globally $[11,12]$.

In the United States, the U.S. Environmental Protection Agency (USEPA) estimated that large-scale dairy operations (>500 cows) have the potential to produce $7 \mathrm{TWhy}^{-1}$ of renewable energy [13], while small-scale dairy operations

\footnotetext{
* Corresponding author. Tel.: +1 301405 1197; fax: +1 3013149023.

E-mail address: slansing@umd.edu (S.A. Lansing). 
( $<500$ cows) have the potential to produce an additional $3 \mathrm{TWh} \mathrm{y}^{-1}$ (0.78 $\mathrm{MWh} \mathrm{y}^{-1}$ per cow) $[14,15]$.

The number of digesters operating on large-scale livestock operations in the U.S. has increased from approximately 100 facilities in 2005 to 171 facilities in July 2011 [16,17]. However, the USEPA does not recommend these systems for facilities with less than 500 cows, as the average capital investment cost of 1.5 million (US\$) per system (2010 US\$), is not feasible for smaller operations $[13,16,18]$, while other studies have shown that 200-400 cows are needed for anaerobic digestion systems to be economically viable $[19,20]$. In $2007,89 \%$ of U.S. dairy farms had less than 200 cows, making digestion technology economically inaccessible to the majority of U.S. dairy farms [15].

There are a number of factors, in addition to high capital costs, influencing the economic viability of small-scale anaerobic digesters. One of these factors is the ability to create sufficient revenue from the digester. While electricity generation can be economically successful at large-scale operations [21,22], success is less likely for small-scale operations, which can be affected more acutely by the price of electricity and are less likely to have the capital to purchase and maintain an electric generator [9,19,23-26]. In lieu of electricity production, the direct use of biogas can be economically feasible when on-farm heating requirements are high enough to utilize the produced biogas throughout the year $[10,27]$. Additionally, carbon credits, tipping fees (for adding off-farm food waste to the digester), and reuse of the solids separated from the digester effluent (as dairy herd bedding or sold as soil amendments) have been shown to increase the economical viability of digesters [9,10,25,28-32].

In addition to increasing revenue opportunities, the use of an anaerobic digester to reduce odors is an important reason for digester installation $[3,19,28,29]$. While hard to quantify, and often not included in economic assessments, costs of odor control could be considered the price of staying in business as residential areas continue to encroach on once-rural U.S. farms [29].

Additional factors affecting the economic viability of digesters include financing and access to data. The main challenge to financing anaerobic digesters in the U.S. is the lack of information regarding initial capital investment, predicted biogas production, expected lifetime, future electricity prices, operating costs, and non-market benefits [25,32]. The AgSTAR Program, an outreach program of the U.S. Environmental Protection Agency (USEPA), U.S. Department of Agriculture (USDA), and U.S. Department of Energy (USDOE) released a protocol for quantifying and reporting digestion performance, but it is expected to take years to collect a comprehensive database [33].

\subsection{Objectives}

In the U.S., small-operations dominate the dairy sector but are not encouraged to build anaerobic digestion systems due to the high capital investment. The objective of this study was to determine the economic viability of small-scale U.S. digesters and to determine how new and existing systems could be designed or altered to improve economic sustainability in the agricultural market. Cost data from nine existing and seven theoretical systems were used to quantify the potential revenue streams needed to make the digesters cost effective and to reevaluate the minimum size dairy farm needed for economically feasible anaerobic digestion in the U.S.

\section{Methods}

\subsection{Small-scale digestion system descriptions}

The evaluation contained economic data from nine existing and seven theoretical U.S. digesters for dairy farms with 250 cows or less. The digester types included upright, plug-flow, covered lagoon, fixed-film, and upflow blanket reactor. Existing systems' cost data were compiled from published studies and interviews of providers and farmers, while theoretical digesters' cost data were derived from published reports [34-46]. The digestion systems used in the economic analysis are listed in Table 1.

Four of the existing systems were installed as part of a research or outreach program. D1, an upright mixed digester, received separated manure with the undigested solids being composted and field applied. D2, a plug-flow digester, received un-separated manure with solids potentially reused as bedding material [34,35]. D3, an upflow-tank reactor or induced blanket reactor, received un-separated manure with the digested solids being recycled as bedding material [36]. The system was designed to primarily use biogas in a generator but had a backup boiler in the event of generator failure [36]. D7, a fixed-film digester constructed with a biofilter, received separated manure with solids being reused as bedding or field applied [38,39].

The remaining four existing systems were installed on private dairies. D4, a horizontal plug-flow digester, received un-separated manure and included U-shaped tank with a modified plastic greenhouse cover to capture biogas [40]. D5, a fixed-film digester, used corrugated plastic drainage tiles as the fixed media and received separated liquid manure [41]. The removed solids were composted with heat from the digester's boilers and used as bedding [41]. D6, a covered lagoon system utilizing a two-tank manure activation system, included a small seeding tank and a main treatment lagoon with a flexible cover [42]. No solid separation equipment was included in this system [42]. D8, an upright mixed digester, received un-separated manure and was designed as two insulated glass-lined steel tanks with silo roofs to collect biogas [43]. The digester used biogas directly in a boiler to heat the digester and produce steam for the farm, or in a generator to produce emergency electricity. This digester was analyzed under both scenarios: boiler used, $\mathrm{D} 8_{\mathrm{a}}$, or generator used, D8 ${ }_{b}[43]$.

Five of the theoretical systems were from a report by the Minnesota Project highlighting different digester designs that could be applied to small-scale dairy farms [44]. T1, a covered pond, was designed as a lined basin with an insulated cover in which the solids could be removed before digestion and composted or removed when digestion pond was emptied. T2, a conventional plug-flow digester, was designed for high solids (12\%) with an elongated tank, flexible cover, and a solid separator post-digestion. T3, an upright unmixed digester, 


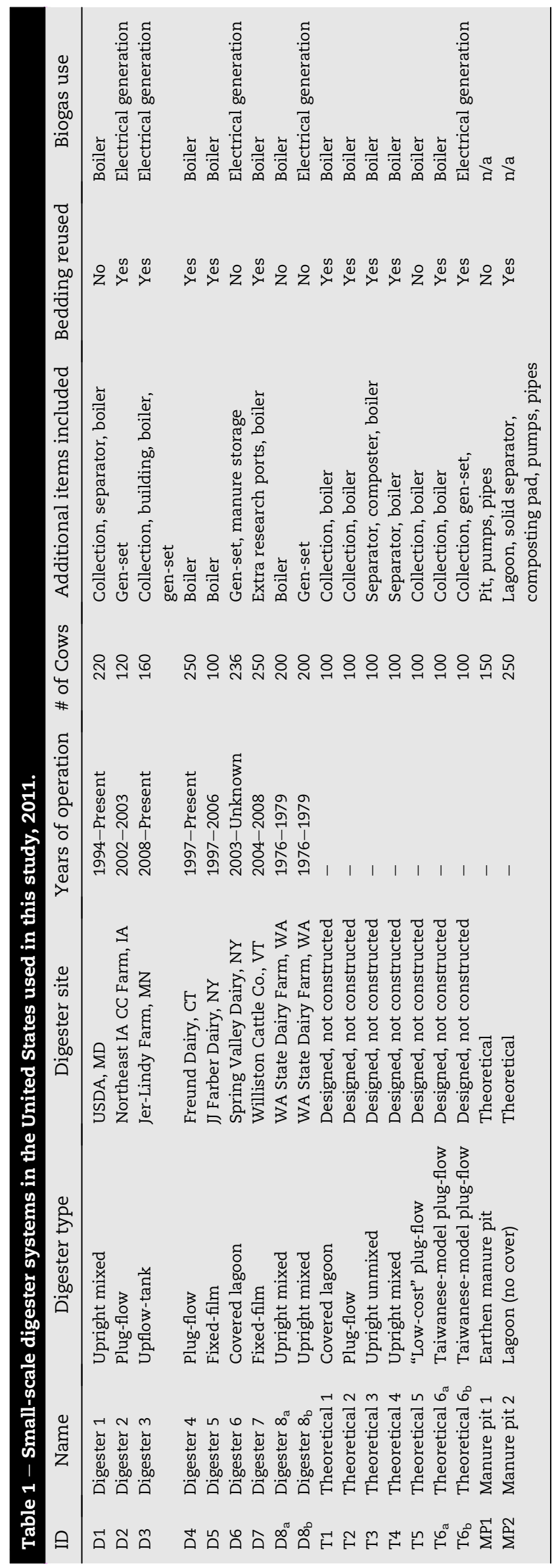

was designed for separated manure with the solids separated and composted prior to digestion. T4, an upright mixed digester, was designed for un-separated manure and thus had a larger tank volume than T3. T5, a low-cost plug-flow system, was designed using a plastic liner inside a steel culvert.

T6 was from an analysis conducted by the University of Maryland (UMD) [45]. The UMD conceptual digester design was a modified version of the traditional Taiwanese-model digester and had a PVC-based tubular bag digester inside an insulated and heated culvert. $\mathrm{T}_{\mathrm{a}}$ was calculated without electricity generation, while $\mathrm{T} \sigma_{\mathrm{b}}$ included an electric generation system (accounting for $36 \%$ of the capital costs).

In addition to data from the 16 digesters, average capital cost data for two types of manure pit systems, an earthen pit without solid separation and a concrete lagoon with solid separation and composting, were collected to demonstrate the costs of traditional manure management systems. The capital costs and operation and maintenance costs of these two systems were calculated based on the records from five farmers (three with earthen pits and two with lagoons and solid separation). It was assumed that the lagoon system with solid separation and composting reused bedding.

\subsection{Cash flow analysis}

The economic viability of each system was evaluated using a cash flow approach and methodology recommended by AgSTAR [33]. The cash flow approach tabulates and compares all annual costs and revenues. The useful life of the system was assumed to be 20 years with replacement cost of system components with shorter lifetimes accounted for in annual operation and maintenance costs. The discount rate on borrowed capital was assumed to be the average effective annual interest rate $\left(8 \% \mathrm{y}^{-1}\right)$ of non-real-estate farm loans in 2010 $[33,47]$.

Published operation and maintenance costs were available for four systems (D3-D6). If records were not available on annual operation and maintenance costs, the cost were assumed to be $3 \%$ of the total capital costs for boiler-only systems, following the recommendations of AgSTAR [33]. As other studies have found annual operation and maintenance costs for digesters with electrical generation to be $5 \%$ of total capital costs, this value was used for electrical generation systems $[1,37,46]$.

Boundary conditions were established to include only components required solely for the digester system. It was assumed that manure storage and spreading systems were already installed on the farm.

\subsection{Annual revenue}

The revenue streams analyzed included biogas production, electrical generation (where appropriate), sale of digester solids for bedding (termed "bedding reuse"), and carbon credit offsets. For systems without generators, it was assumed that all produced biogas not used to heat the digester was utilized on the farm to offset the cost of natural gas that would have been purchased at the average 2010-2011 agricultural consumer rate for natural gas, $0.18 \$ \mathrm{~m}^{-3}$ (2010 US\$) [48]. If biogas production data was not provided, it was assumed that one 
cow produced $2.0 \mathrm{~m}^{3} \mathrm{~d}^{-1}$ of biogas, which is comparable to the $1.9 \mathrm{~m}^{3} \mathrm{~d}^{-1}$ calculated by the Natural Resources Conservation Service (NRCS) $[14,46]$. It was also assumed that the produced biogas contained $60 \%$ methane by volume, one-third of which was used to heat the digester leaving two-thirds for revenue considerations $[14,27,46]$.

For systems with generators, it was assumed that $1.0 \mathrm{kWh}$ was produced from $0.9 \mathrm{~m}^{3}$ of biogas, offsetting electricity that would have been purchased by the farm at 2010 retail prices, $90 \$ \mathrm{MW} \mathrm{h}^{-1}$ (2010 US\$) [14,49], which is within the range of 80-140 \$ MW $\mathrm{h}^{-1}$ (2010 US\$) used in previous economic evaluations of anaerobic digesters in the U.S. [19,24,26]. Additionally, it was assumed that farms had net metering pricing, which allows renewable energy operations to receive retail value for excess electricity produced $[50,51]$. In the United States, net metering laws have been enacted in 46 States, but laws vary from State to State and do not always include biogas production as an eligible renewable energy source [52].

Revenue values from bedding reuse were calculated based on the assumption that a dairy cow produces approximately $7.65 \mathrm{~m}^{3} \mathrm{y}^{-1}$ of fiber $[53,54]$ and bedding costs average $13 \$ \mathrm{~m}^{-3}$ (2010 US\$) [54,55]. It was assumed that only digestion systems with solid separation equipment could receive revenue from bedding reuse.

Carbon emission reduction calculations were based on the AgSTAR Reporting Protocol-Section 6.0: Reduction in Methane Emissions, with the following correction made to Table 4 of this Protocol [33]. The default value of $\mathrm{kg} \mathrm{CH}_{4}$ emitted was listed in Table 4 as $10^{-6} \mathrm{Btu}(0.01 \mathrm{~J})$ [33]. This value was corrected to $10^{-9} \mathrm{Btu}(0.01 \mathrm{E}-3 \mathrm{~J})$, as specified in the IPCC Guidelines for National Greenhouse Gas Inventories [56]. A carbon credit cost of $5.70 \$ \mathrm{t}^{-1}(2010 \$) \mathrm{CO}_{2}-\mathrm{C}$ equivalent was used, which has been used in other economic assessments and is within the range traded on the Chicago Climate Exchange between 2008 and 2011 [50,57].

All costs and results were converted to and reported in 2010 U.S. dollars using the Engineering News Record (ENR) Construction Cost Index [58-62].

\subsection{Sensitivity analysis}

A sensitivity analysis was conducted for the annual discount rate (4\% and $8 \%$ ) and lifetime expectancy (10 and 20 years), with an $8 \%$ discount rate and 20 -year lifetime representing the base-case scenario and a $4 \%$ discount rate and 20 -year lifetime representing the best-case scenario. In the literature, discount rates range from 4.0 to $14.25 \%$ and lifetime expectancies range from 10 to 20 years $[9,10,24,26,27,33]$. In addition, cost sharing of $50 \%$ of capital cost was analyzed under each scenario.

\section{Results}

\subsection{Capital costs}

Capital costs per cow generally decreased with increasing herd size (Fig. 1). However, no other relationships were evident between capital costs and digester design, or the presence or absence of electrical generators. Capital costs of the 16 systems ranged from 120,000 to $490,000 \$$ with capital

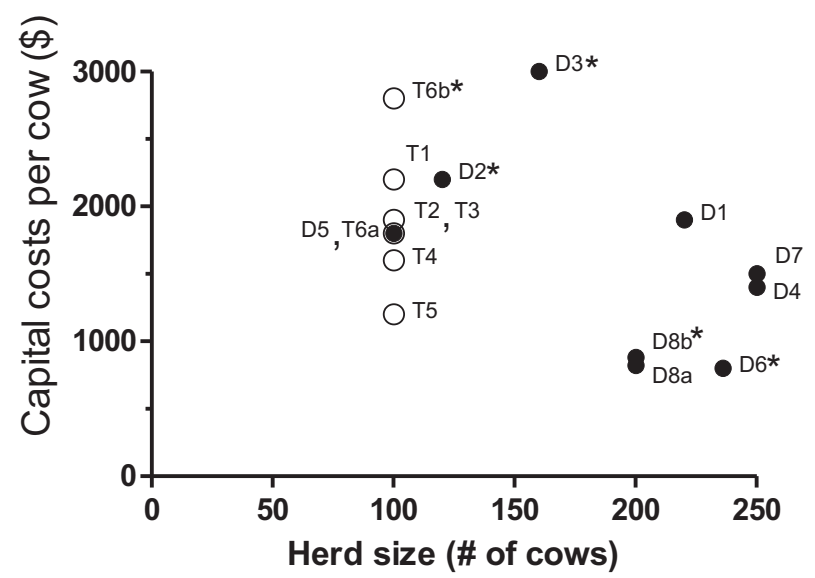

Fig. 1 - Capital costs per cow as a function of farm herd size. Values from existing digester systems are shown as solid circles. Values from theoretical digester systems are shown as open circles. The five systems that include electrical generators are marked with asterisks.

costs per cow generally ranging between $1400 \$$ and $2200 \$$ (Table 2). Costs of the theoretical systems spanned the same cost range as those of existing systems (Fig. 1).

With respect to capital costs of different digester designs, covered lagoon systems were represented by the least expensive system (D6) as well as one of the most expensive systems (T1) in the group. The second least expensive system (D8) was an upright mixed digester constructed in 1976. Systems on larger dairies ( $>200$ cows) with electrical generators (D6, D8 $8_{b}$ had comparable net costs per cow to those of systems without generators (D4, D7, D8a). However, systems on smaller dairies (100-160 cows) with electrical generators (D2, D3, $T 6_{b}$ ) had higher costs per cow than those of comparable dairies without electrical generators (D1, D5, T1-T5, T6a) (Fig. 1).

\subsection{Operating costs}

Annual operating costs ranged from $25 \%$ to $50 \%$ of annual capital costs (Table 2). The exception was D5, where the annual operating cost was $30 \%$ greater than its annual capital costs and represented $18 \%$ of total capital costs. These values came from a case study and included insurance, reporting, and manure spreading costs [41]. If an operating cost of $3 \%$ had been used, D5 would still have had a negative cash flow but would have increased from the least economical system to the 5th most economical of the 16 systems. The other three systems where existing data were used (D3, D4 and D6) had annual operating costs of $3 \%, 6 \%$, and $6 \%$ of total capital costs, respectively $[37,42]$.

The majority of the operating costs ranged between $40 \$$ and $60 \$$ per cow and did not appear to be dependent on the size of the herd nor the inclusion of a generator (Table 2). The only types of systems to have operating costs greater than $100 \$$ per cow were plug-flow (D2 and T6b) and fixed-film (D5) systems (Table 2). When operating costs of $5 \%$ and $3 \%$ were used instead of the published operating costs for D3, D6 and 
Table 2 - Cash flow analysis for the small-scale digestion systems. Parentheses represent a negative number (2010 US\$).

\begin{tabular}{|c|c|c|c|c|c|c|c|c|c|}
\hline ID & $\begin{array}{l}\text { Capital } \\
\text { costs }\end{array}$ & $\begin{array}{c}\text { Capital } \\
\text { cost/cow }\end{array}$ & $\begin{array}{l}\text { Annual } \\
\text { capital } \\
\text { costs }^{a}\end{array}$ & $\begin{array}{l}\text { Annual } \\
\text { operating } \\
\text { cost }^{\mathrm{b}}\end{array}$ & $\begin{array}{l}\text { Annual } \\
\text { operating cost } \\
\text { per cow }\end{array}$ & $\begin{array}{l}\text { Annual } \\
\text { revenue }^{c}\end{array}$ & $\begin{array}{c}\text { Annual } \\
\text { net cost }\end{array}$ & $\begin{array}{l}\text { Annual net } \\
\text { cost/cow }^{\mathrm{e}}\end{array}$ & $\begin{array}{l}\text { Potential annual } \\
\text { net cost/cow } \\
\text { including } \\
\text { bedding reuse }\end{array}$ \\
\hline D1 & $(\$ 430,000)$ & (\$1900) & $(\$ 44,000)$ & $(\$ 13,000)$ & $(\$ 59)$ & $\$ 14,000$ & $(\$ 43,000)$ & $(\$ 200)$ & (\$91) \\
\hline D2 ${ }^{g}$ & $(\$ 270,000)$ & $(\$ 2200)$ & $(\$ 27,000)$ & $(\$ 13,000)$ & (\$110) & $\$ 18,000$ & $(\$ 22,000)$ & $(\$ 180)$ & \\
\hline D3 ${ }^{g}$ & $(\$ 490,000)$ & (\$3000) & $(\$ 50,000)$ & $(\$ 13,000)$ & $(\$ 81)$ & $\$ 25,000$ & $(\$ 38,000)$ & $(\$ 240)$ & \\
\hline D4 & $(\$ 350,000)$ & (\$1400) & $(\$ 36,000)$ & $(\$ 22,000)$ & (\$88) & $\$ 40,000$ & $(\$ 18,000)$ & (\$72) & \\
\hline D5 & $(\$ 180,000)$ & (\$1800) & $(\$ 18,000)$ & $(\$ 32,000)$ & $(\$ 320)$ & $\$ 16,000$ & $(\$ 34,000)$ & $(\$ 340)$ & \\
\hline $\mathrm{D} 6^{\mathrm{g}}$ & $(\$ 190,000)$ & $(\$ 800)$ & $(\$ 19,000)$ & $(\$ 11,000)$ & $(\$ 47)$ & $\$ 13,000$ & $(\$ 17,000)$ & $(\$ 72)$ & (\$3) \\
\hline D7 & $(\$ 370,000)$ & (\$1500) & $(\$ 38,000)$ & $(\$ 11,000)$ & (\$44) & $\$ 40,000$ & (\$9000) & (\$36) & \\
\hline $\mathrm{D} 8 \mathrm{a}_{\mathrm{a}}$ & $(\$ 160,000)$ & $(\$ 820)$ & $(\$ 16,000)$ & $(\$ 4900)$ & $(\$ 25)$ & $\$ 12,000$ & (\$8900) & $(\$ 45)$ & $\$ 12$ \\
\hline$D 8^{g}{ }^{g}$ & $(\$ 180,000)$ & $(\$ 880)$ & $(\$ 18,000)$ & $(\$ 8800)$ & $(\$ 44)$ & $\$ 11,000$ & $(\$ 16,000)$ & $(\$ 80)$ & (\$25) \\
\hline $\mathrm{T} 1$ & $(\$ 220,000)$ & (\$2200) & $(\$ 22,000)$ & (\$6500) & (\$65) & $\$ 16,000$ & $(\$ 13,000)$ & (\$130) & \\
\hline T2 & $(\$ 190,000)$ & (\$1900) & $(\$ 19,000)$ & $(\$ 5800)$ & (\$58) & $\$ 16,000$ & $(\$ 8800)$ & $(\$ 88)$ & \\
\hline T3 & $(\$ 190,000)$ & (\$1900) & $(\$ 19,000)$ & $(\$ 5700)$ & (\$57) & $\$ 16,000$ & $(\$ 8700)$ & (\$87) & \\
\hline $\mathrm{T} 4$ & $(\$ 160,000)$ & (\$1600) & $(\$ 16,000)$ & $(\$ 4900)$ & $(\$ 49)$ & $\$ 16,000$ & $(\$ 4900)$ & (\$49) & \\
\hline T5 & $(\$ 120,000)$ & (\$1200) & $(\$ 12,000)$ & (\$3700) & (\$37) & $\$ 6000$ & (\$9700) & (\$97) & (\$70) \\
\hline $\mathrm{T} 6_{\mathrm{a}}$ & $(\$ 180,000)$ & (\$1800) & $(\$ 18,000)$ & (\$5500) & (\$55) & $\$ 16,000$ & (\$7500) & (\$75) & \\
\hline $\mathrm{T} 6_{\mathrm{b}}{ }^{\mathrm{g}}$ & $(\$ 280,000)$ & $(\$ 2800)$ & $(\$ 29,000)$ & $(\$ 14,000)$ & $(\$ 140)$ & $\$ 15,000$ & $(\$ 28,000)$ & $(\$ 280)$ & \\
\hline MP1 & $(\$ 150,000)$ & (\$1000) & $(\$ 15,000)$ & $(\$ 15,000)$ & (\$100) & $\$ 0$ & $(\$ 30,000)$ & $(\$ 200)$ & \\
\hline MP2 & $(\$ 600,000)$ & (\$2400) & $(\$ 61,000)$ & $(\$ 25,000)$ & (\$100) & $\$ 25,000$ & $(\$ 61,000)$ & $(\$ 240)$ & \\
\hline
\end{tabular}

a Values calculated using an $8 \%$ annual discount rate and 20 -year lifetime.

b Values calculated using 3-5\% of total capital costs or from literature values as described in text.

c Values calculated by summing income from biogas use, bedding reuse, and $\mathrm{CO}_{2} \mathrm{Credits}$ as shown in Table 4 .

d Values calculated by summing annual capital costs, annual operating costs, and annual revenue.

e Values calculated by dividing the annual net cost by the number of cows utilizing the digester.

$\mathrm{f}$ Values calculated by dividing the annual net cost, including potential revenue from bedding reuse, by the number of cows utilizing the digester. The cost of the separator $(50,000 \$$ for $\mathrm{T} 5$ and $60,000 \$$ for $\mathrm{D} 6, \mathrm{D} 8 \mathrm{a}$, and D8 $\mathrm{b}$ ) was added to the capital cost in order for bedding reuse to be a potential revenue source.

g Includes electrical generation.

D4, D5, respectfully, D3 has an operating cost of $150 \$$ per cow and D4-D6 had operating cost of 40-53\$ per cow (not shown).

\subsection{Cash flow and sensitivity analyses}

A cash flow analysis identified no digestion systems with a positive cash flow using an $8 \% \mathrm{y}^{-1}$ discount rate and 20 -year lifetime (Table 2). In general, systems that utilized biogas directly (D1, D4, D5, D7, D8 a T1-T5, T6a) had lower net costs per cow (with eight out of 11 having annual net costs per cow under 100\$) than the five systems (D2, D3, D6, D8 b, T6 $6_{b}$ ) with electrical generation. Cost sharing improved cash flow values more than reducing the interest rate (Table 3, Fig. 2). Under the best-case scenario of $4 \% \mathrm{y}^{-1}$ interest over a 20 -year lifetime without cost sharing, only digester D7 had a positive cash flow. However, six of 16 systems (D4, D7, T2-T4, and T6a) had a positive cash flow using $8 \% \mathrm{y}^{-1}$ interest over a 20 -year lifetime with $50 \%$ cost sharing.

\subsection{Revenue streams}

Details of the revenue streams from the digestion systems are shown in Table 4. Bedding reuse was the highest revenue source $\left(100 \$ \mathrm{y}^{-1}\right.$ per cow), roughly twice the revenue from biogas production (Table 4). When costs and revenue from bedding reuse were added to the five systems without solid separation capabilities (D1, D6, D8 $8_{a}, \mathrm{D} 8$, and T5), two developed a positive cash flow (D6 and $\mathrm{D} 8_{\mathrm{a}}$ ) under the base-scenario
( $8 \% \mathrm{y}^{-1}$ discount rate, 20 -year lifetime) (Table 2, Table 4) and one $\left(\mathrm{D} 8_{\mathrm{b}}\right.$ ) developed a positive cash flow under the best-case scenario $\left(4 \% \mathrm{y}^{-1}\right.$ discount rate and 20-year lifetime) (not shown). Neither D1 (which already included a separator) nor T5 developed a positive cash flow under any scenario without cost sharing. Thus, the addition of a separator did increase revenue, but not always enough to overcome the initial capital investment. Based on the bedding and economic assumptions of this analysis, the initial capital cost of a separation systems $(60,000 \$$ for 250 cow system and $50,000 \$$ for 100 cow system) would be recovered in 3.5 and 15 years, respectively (not shown).

Given the 2010 prices of natural gas $\left(0.18 \$ \mathrm{~m}^{-3}\right)$ and electricity $\left(90 \$ \mathrm{MW} \mathrm{h}^{-1}\right)$, it was slightly more cost effective to use biogas directly $\left(53 \$ \mathrm{y}^{-1}\right.$ per cow) than to convert biogas to electricity $\left(47 \$ y^{-1}\right.$ per cow) (Table 4$)[48,49]$. However, if the digester was heated solely with waste heat from the generator and $100 \%$ of the biogas was used for electricity generation, potential revenue from electricity increased $\left(70 \$ \mathrm{y}^{-1}\right.$ per cow). This increase was insufficient to generate a positive cash flow for any of the digesters using electrical generation (not shown).

The annual electricity generation potential per cow was calculated as $0.8 \mathrm{MWh}$, which is in the range used in other analyses $\left(0.4-3.9 \mathrm{MWh} \mathrm{y}^{-1}\right)[8,63]$. If the electricity generation potential was doubled to $1.6 \mathrm{MWhy}^{-1}$, the systems with electricity generation (D2, D3, D6, D8 $8_{b}$, and $T 6_{b}$ ) would still have a negative cash flow. D6 and $D 8_{b}$ became cost neutral at 
Table 3 - Sensitivity analysis of cash flow for the small-scale digestion systems. Parentheses represent a negative number (2010 US\$).

\begin{tabular}{|c|c|c|c|c|c|c|c|c|}
\hline ID & $\begin{array}{c}4 \%, 10 \text { (No } \\
\text { cost sharing) }\end{array}$ & $\begin{array}{c}4 \%, 10(50 \% \\
\text { Cost sharing) }\end{array}$ & $\begin{array}{c}4 \%, 20 \text { (No } \\
\text { cost sharing) }\end{array}$ & $\begin{array}{c}4 \%, 20(50 \% \\
\text { cost sharing) }\end{array}$ & $\begin{array}{c}8 \%, 10 \text { (No } \\
\text { cost sharing) }\end{array}$ & $\begin{array}{c}8 \%, 10(50 \% \\
\text { Cost sharing) }\end{array}$ & $\begin{array}{c}8 \%, 20 \text { (No } \\
\text { cost sharing) }\end{array}$ & $\begin{array}{c}8 \%, 20(50 \% \\
\text { Cost sharing) }\end{array}$ \\
\hline D1 & $(\$ 52,000)$ & $(\$ 25,000)$ & $(\$ 31,000)$ & $(\$ 15,000)$ & $(\$ 63,000)$ & $(\$ 31,000)$ & $(\$ 43,000)$ & $(\$ 21,000)$ \\
\hline D2 & $(\$ 28,000)$ & $(\$ 11,000)$ & $(\$ 15,000)$ & $(\$ 4800)$ & $(\$ 35,000)$ & $(\$ 15,000)$ & $(\$ 22,000)$ & $(\$ 8600)$ \\
\hline D3 & $(\$ 48,000)$ & $(\$ 18,000)$ & $(\$ 24,000)$ & (\$5900) & $(\$ 61,000)$ & $(\$ 24,000)$ & $(\$ 38,000)$ & $(\$ 13,000)$ \\
\hline D4 & $(\$ 25,000)$ & $(\$ 3600)$ & $(\$ 7800)$ & $\$ 5100$ & $(\$ 34,000)$ & $(\$ 8100)$ & $(\$ 18,000)$ & $\$ 180$ \\
\hline D5 & $(\$ 38,000)$ & $(\$ 27,000)$ & $(\$ 29,000)$ & $(\$ 22,000)$ & $(\$ 42,000)$ & $(\$ 29,000)$ & $(\$ 34,000)$ & $(\$ 25,000)$ \\
\hline D6 & $(\$ 21,000)$ & (\$9600) & $(\$ 12,000)$ & $(\$ 4900)$ & $(\$ 26,000)$ & $(\$ 12,000)$ & $(\$ 17,000)$ & $(\$ 7600)$ \\
\hline D7 & $(\$ 17,000)$ & $\$ 6100$ & $\$ 1700$ & $\$ 15,000$ & $(\$ 26,000)$ & $\$ 1300$ & $(\$ 8800)$ & $\$ 10,000$ \\
\hline D8a & $(\$ 13,000)$ & (\$3000) & $(\$ 5000)$ & $\$ 1000$ & $(\$ 17,000)$ & $(\$ 5200)$ & (\$9700) & $(\$ 1300)$ \\
\hline D8b & $(\$ 20,000)$ & $(\$ 8700)$ & $(\$ 11,000)$ & $(\$ 4300)$ & $(\$ 24,000)$ & $(\$ 11,000)$ & $(\$ 16,000)$ & $(\$ 6800)$ \\
\hline T1 & $(\$ 17,000)$ & $(\$ 3900)$ & $(\$ 6500)$ & $\$ 1500$ & $(\$ 23,000)$ & $(\$ 6700)$ & $(\$ 13,000)$ & $(\$ 1600)$ \\
\hline $\mathrm{T} 2$ & $(\$ 14,000)$ & $(\$ 1700)$ & $(\$ 4000)$ & $\$ 3100$ & $(\$ 19,000)$ & $(\$ 4200)$ & $(\$ 9400)$ & $\$ 390$ \\
\hline T3 & $(\$ 13,000)$ & $(\$ 1400)$ & $(\$ 3600)$ & $\$ 3300$ & $(\$ 18,000)$ & $(\$ 3800)$ & (\$9000) & $\$ 670$ \\
\hline T4 & $(\$ 9,000)$ & $\$ 1000$ & $(\$ 910)$ & $\$ 5100$ & $(\$ 13,000)$ & $(\$ 1100)$ & $(\$ 5500)$ & $\$ 2800$ \\
\hline T5 & $(\$ 13,000)$ & $(\$ 5400)$ & $(\$ 6800)$ & $(\$ 2300)$ & $(\$ 16,000)$ & $(\$ 6900)$ & $(\$ 10,000)$ & $(\$ 4000)$ \\
\hline $\mathrm{T} 6_{\mathrm{a}}$ & $(\$ 12,000)$ & $(\$ 850)$ & $(\$ 3100)$ & $\$ 3700$ & $(\$ 17,000)$ & $(\$ 3200)$ & $(\$ 8300)$ & $\$ 1100$ \\
\hline $\mathrm{T} \sigma_{\mathrm{b}}$ & $(\$ 34,000)$ & $(\$ 17,000)$ & $(\$ 20,000)$ & $(\$ 9500)$ & $(\$ 41,000)$ & $(\$ 20,000)$ & $(\$ 28,000)$ & $(\$ 13,000)$ \\
\hline
\end{tabular}

Boldface signifies a positive value.

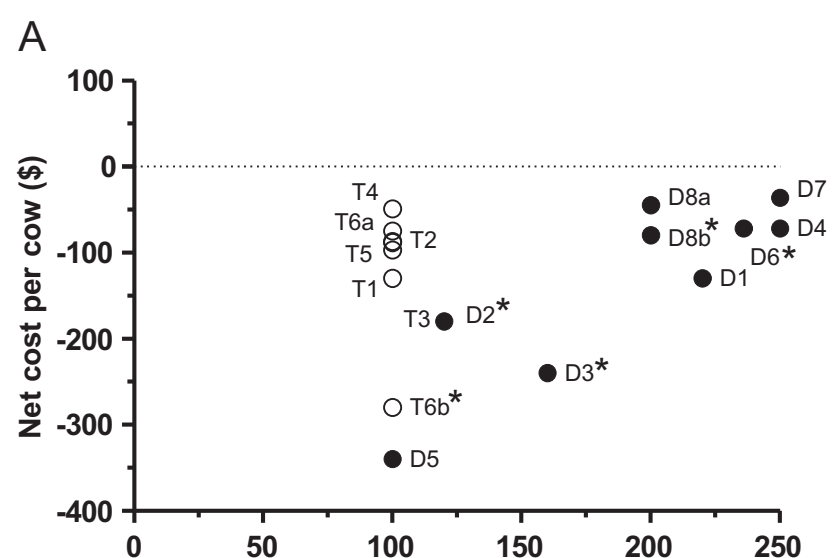

B

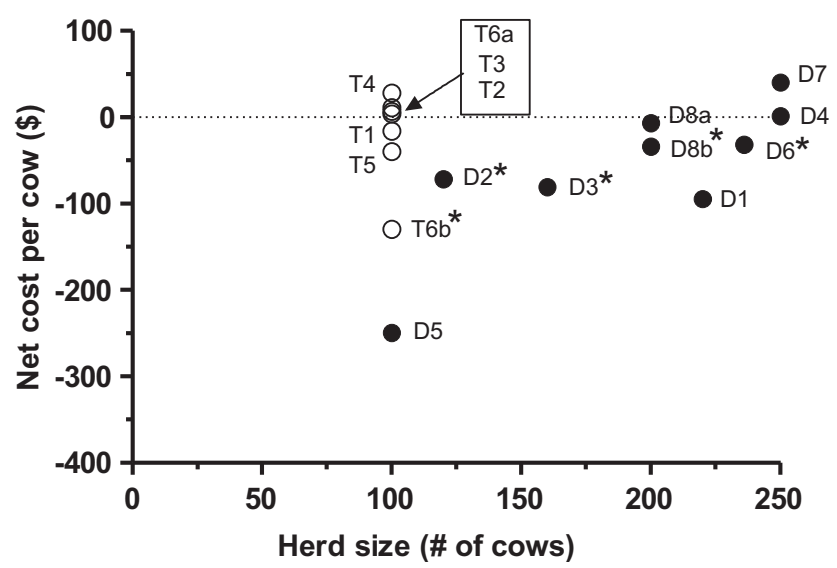

Fig. 2 - Annual net costs per cow as a function of farm herd size. A, values were calculated without cost sharing of capital costs. B, values were calculated using $50 \%$ cost sharing of capital costs. Values from existing digester systems are shown as solid circles. Values from theoretical digester systems are shown as open circles. The five systems that include electrical generators are marked with asterisks.
2.0 and 2.2 $\mathrm{MWh}^{-1}$, respectively. If electrical generation was removed from systems utilizing generators $\left(\mathrm{D} 2, \mathrm{D} 3, \mathrm{D} 6, \mathrm{D} 8_{\mathrm{b}}\right.$, and $\mathrm{T}_{\mathrm{b}}$ ) their respective annual costs decreased but not enough to become cost effective (not shown).

Revenue from carbon credits was the lowest revenue source generated from the digesters $\left(7 \$ \mathrm{y}^{-1}\right.$ per cow) (Table 4). The digesters in this study had carbon emission reductions ranging from $121,000-303,000 \mathrm{~kg} \mathrm{CO}_{2}-\mathrm{C}$ annually, for 100-250 cows, respectively. When the trading cost of carbon is low, such as $0.05 \$ \mathrm{t}^{-1} \mathrm{CO}_{2}-\mathrm{C}$ traded on the Chicago Climate Exchange in 2010 , the annual revenue for each system ranged from 6 to $15 \$$ (not shown) [57]. If the highest rate for $\mathrm{CO}_{2}$ reduction was used, $7.40 \$ \mathrm{t}^{-1} \mathrm{CO}_{2}-\mathrm{C}$ (US\$) traded in June 2008, the annual revenue was $2240 \$$ for a 250 -cow digestion system (not shown).

\section{Discussion}

\subsection{Impacts of size, design, and revenue on cash flow}

Cash flow analysis results showed that total capital costs, capital costs per cow, and net costs per cow generally decreased with increasing herd size in existing systems. Of the 16 systems analyzed, only one (D7) had a positive cash flow under the best-case scenario without cost sharing. The D7 system was on a larger farm (250 cows), had average capital costs per cow $\left(1500 \$ \mathrm{y}^{-1}\right)$, and garnered revenue from direct biogas use, bedding reuse, and $\mathrm{CO}_{2}$ credits. Of the three least cost-effective systems, two had electric generation (D3 and $\mathrm{T} 6_{\mathrm{b}}$ ) and one (D5) did not have electric generation. D3 and $\mathrm{T} 6_{\mathrm{b}}$ had the highest initial capital costs (roughly $\$ 3000 \mathrm{cow}^{-1}$ ), and therefore needed to generate greater annual revenues to create positive cash flows.

While those systems with the highest capital costs were not cost effective, the systems with low capital costs were not necessarily cost effective either. The three systems with lowest capital costs (D6, D8 $8_{\mathrm{a}}$, and $\mathrm{D} 8_{\mathrm{b}}$ ) did not perform positively under any scenario until bedding reuse was added as a 
Table 4 - Annual revenue for the small-scale digestion systems (2010 US\$).

\begin{tabular}{|c|c|c|c|c|c|c|c|c|}
\hline ID & Biogas $^{a}$ & $\begin{array}{l}\text { Electrical } \\
\text { generation }^{\mathrm{b}}\end{array}$ & $\begin{array}{l}\text { Bedding } \\
\text { reuse } \mathrm{C}^{\mathrm{C}}\end{array}$ & $\begin{array}{c}\mathrm{CO}_{2} \\
\text { credits }^{\mathrm{d}}\end{array}$ & $\begin{array}{l}\text { Total } \\
\text { revenue }\end{array}$ & $\begin{array}{l}\text { Total revenue } \\
\text { per cow }^{\mathrm{f}}\end{array}$ & $\begin{array}{l}\text { Potential total } \\
\text { revenue including } \\
\text { bedding reuse }\end{array}$ & $\begin{array}{l}\text { Total potential } \\
\text { revenue per cow }\end{array}$ \\
\hline D1 & $\$ 12,000$ & $\$ 0$ & $\$ 0$ & $\$ 1500$ & $\$ 14,000$ & $\$ 64$ & $\$ 36,000$ & $\$ 160$ \\
\hline D2 & $\$ 0$ & $\$ 5600$ & $\$ 12,000$ & $\$ 810$ & $\$ 18,000$ & $\$ 150$ & & \\
\hline D3 & $\$ 0$ & $\$ 7500$ & $\$ 16,000$ & $\$ 1100$ & $\$ 25,000$ & $\$ 160$ & & \\
\hline D4 & $\$ 13,000$ & $\$ 0$ & $\$ 25,000$ & $\$ 1700$ & $\$ 40,000$ & $\$ 160$ & & \\
\hline D5 & $\$ 5300$ & $\$ 0$ & $\$ 10,000$ & $\$ 690$ & $\$ 16,000$ & $\$ 160$ & & \\
\hline D6 & $\$ 0$ & $\$ 11,000$ & $\$ 0$ & $\$ 1600$ & $\$ 13,000$ & $\$ 55$ & $\$ 37,000$ & $\$ 160$ \\
\hline D7 & $\$ 13,000$ & $\$ 0$ & $\$ 25,000$ & $\$ 1700$ & $\$ 40,000$ & $\$ 160$ & & \\
\hline D8a & $\$ 11,000$ & $\$ 0$ & $\$ 0$ & $\$ 1400$ & $\$ 12,000$ & $\$ 60$ & $\$ 32,000$ & $\$ 160$ \\
\hline $\mathrm{D} 8 \mathrm{~b}$ & $\$ 0$ & $\$ 9400$ & $\$ 0$ & $\$ 1300$ & $\$ 11,000$ & $\$ 55$ & $\$ 31,000$ & $\$ 160$ \\
\hline $\mathrm{T} 1$ & $\$ 5300$ & $\$ 0$ & $\$ 10,000$ & $\$ 690$ & $\$ 16,000$ & $\$ 160$ & & \\
\hline T2 & $\$ 5300$ & $\$ 0$ & $\$ 10,000$ & $\$ 690$ & $\$ 16,000$ & $\$ 160$ & & \\
\hline T3 & $\$ 5300$ & $\$ 0$ & $\$ 10,000$ & $\$ 690$ & $\$ 16,000$ & $\$ 160$ & & \\
\hline $\mathrm{T} 4$ & $\$ 5300$ & $\$ 0$ & $\$ 10,000$ & $\$ 690$ & $\$ 16,000$ & $\$ 160$ & & \\
\hline T5 & $\$ 5300$ & $\$ 0$ & $\$ 0$ & $\$ 690$ & $\$ 6000$ & $\$ 60$ & $\$ 16,000$ & $\$ 160$ \\
\hline $\mathrm{T} 6_{\mathrm{a}}$ & $\$ 5300$ & $\$ 0$ & $\$ 10,000$ & $\$ 690$ & $\$ 16,000$ & $\$ 160$ & & \\
\hline $\mathrm{T} 6_{\mathrm{b}}$ & $\$ 0$ & $\$ 4700$ & $\$ 10,000$ & $\$ 670$ & $\$ 15,000$ & $\$ 150$ & & \\
\hline MP1 & $\$ 0$ & $\$ 0$ & $\$ 0$ & $\$ 0$ & $\$ 0$ & $\$ 0$ & & \\
\hline MP2 & $\$ 0$ & $\$ 0$ & $\$ 25,000$ & $\$ 0$ & $\$ 25,000$ & $\$ 100$ & & \\
\hline
\end{tabular}

a Values calculated assuming an annual per cow biogas production of $730 \mathrm{~m}^{3}$, a methane content of $60 \%$ by volume, with two-thirds of the biogas available after digester heating, and a price of $0.18 \mathrm{US} \$ \mathrm{~m}^{-3}$ equal to (53 $\$ \mathrm{y}^{-1}$ per cow) (2010 US\$).

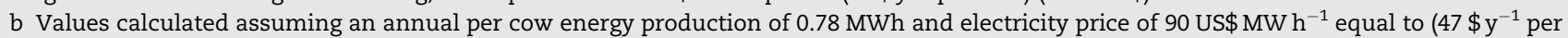
cow) (2010 US\$).

c Values calculated assuming one dairy cow produces $7.65 \mathrm{~m}^{-3}$ of fiber per year and bedding costs average 13 US $\$ \mathrm{~m}^{-3}$ equal to $\left(100 \$ \mathrm{y}^{-1}\right.$ per cow) (2010 US\$).

$\mathrm{d}$ Values calculated assuming an annual $\mathrm{CO}_{2}$ reduction of $1181 \mathrm{~kg}$ per cow and $5.70 \mathrm{US}^{\mathrm{t}} \mathrm{t}^{-1} \mathrm{CO}_{2}$-C equivalent equal to $\left(7 \$ \mathrm{y}^{-1}\right.$ per cow) (2010 US\$).

e Values calculated by summing revenue sources.

$\mathrm{f}$ Values calculated by dividing total revenue by the number of cows.

$\mathrm{g}$ These digestion systems do not currently reuse bedding. The potential income were bedding reuse instituted was calculated assuming one dairy cow produces $7.65 \mathrm{~m}^{-3}$ of fiber per year and bedding costs average $13 \mathrm{US} \$ \mathrm{~m}^{-3}$ equal to (100 $\$ \mathrm{y}^{-1}$ per cow) (2010 US\$).

$\mathrm{h}$ Values calculated by dividing total potential revenue by the number of cows.

revenue source. In addition, D8 was built in 1976 . While all costs were adjusted using the construction cost index, it is possible that the cost to build the same system today would be higher than the extrapolated cost, as the construction cost index does not reflect an exact inflation rate for all materials used in the construction of a digester.

Among existing revenue streams, use of digested solids for bedding generated the highest revenue $\left(\$ 100 \mathrm{cow}^{-1}\right.$ year $\left.^{-1}\right)$, followed by biogas use for heating and/or electrical generation $\left(\$ 47\right.$ to $\$ 70$ cow $^{-1}$ year $^{-1}$ ) and $\mathrm{CO}_{2}$ credits $\left(\$ 7 \mathrm{cow}^{-1}\right.$ year $^{-1}$ ). When utilized, bedding reuse accounted for approximately $60 \%$ of income. This result is consistent with previous studies that have found bedding recycling for on-farm use or for offfarm sale to be an important revenue source for farms with solid separation capabilities $[10,29,30,53]$. The estimated revenue for D4 $(40,000 \$)$ was $24,000 \$$ higher than estimated in a previous study due to greater savings calculated for bedding reuse and biogas use in the previous study [40]. It should be noted that cost of the separation system used in this analysis $(60,000 \$$ for 250 cow system and 50,000\$ for 100 cow system) is an average cost. Economic analyses have shown the cost of separators can range from 17,000 to $54,000 \$$, and the cost of separators plus the building and related separator equipment can range from 46,000 to $71,000 \$[29,37,41,44]$.

\subsection{Sensitivity of revenue assumptions and cost sharing}

Changes in revenue with respect to biogas use assumptions had minimal affect on the cost effectiveness of the systems. In addition, improving energy production efficiency by using waste heat to heat the digesters or by increasing the generation potential did not change the cost effectiveness of any system. Farmers and experts interviewed in this study observed that farm-scale systems often perform at lower efficiencies than originally predicted. Thus, the more conservative generation potential value used for this economic analysis is likely more accurate for estimating actual field results.

The economic value of the greenhouse gas reductions attributed to digester installation does not greatly increase revenue for a small-scale dairy. This is in agreement with a previous study that predicted even with a trading value of $26 \$ \mathrm{t}^{-1} \mathrm{CO}_{2}-\mathrm{C}$, carbon trading would only be cost effective for $3 \%$ of small-scale ( $<250$ cows) farms [64]. Additional costs not accounted for in this assessment were annual carbon audits. Farmers receiving carbon emission offsets will incur an additional cost associated with initial and annual inspections and verification of their operations, ranging in cost from 3000 to $5000 \$$ for the initial verification and 700 to $1000 \$$ for annual 
carbon audits [65], making carbon credit price neutral or cost prohibitive for smaller operations.

As expected, the inclusion of cost sharing had a positive impact on the cash flow of the systems. There are multiple cost-sharing opportunities available to U.S. farmers for anaerobic digesters. Various U.S. federal, state, and local sources of grants, loans, tax exemptions, and production incentives typically cover up to $50 \%$ of the project costs $[50,66]$. Giesy et al. [24] found that the economic feasibility of digesters was highly sensitive to cost-sharing opportunities. Increased use of cost sharing will likely accelerate the adoption of smallscale digesters.

\subsection{Food waste and tipping fees}

The negative cash flow observed in many systems could be offset by the addition of food waste into the digester and the accompanying tipping fees. For example, to have a positive cash flow, T4 would need an additional $410 \$$ in monthly tipping fees. Seven systems (D7, D8 a, T2-T5, T6a) would have a positive cash flow with the additional revenue from monthly tipping fees of less than $1000 \$$, which, at $0.02 \$$ per gallon, is equivalent to approximately 210 tons (50,000 gallons) of food waste or eight truck loads. Although accepting food waste could also increase biogas production and biogas revenue by contributing additional volatile solids to the digester, operating costs would increase with additional land application costs $[10,67]$.

\subsection{Additional potential revenue sources}

For the 16 systems studied, the additional monthly revenue needed for the systems to have a positive cash flow ranged from 2300 to $740 \$$ in systems without solid separation and from 3200 to $410 \$$ in systems with solid separation. In addition to the traditional revenue sources discussed above, there are potential future revenue sources from innovative uses of biogas and digester by-products and additional savings calculated from the use of anaerobic digesters that were not included in this analysis.

It should be noted that the revenue values calculated in this analysis were less than those calculated in previous studies $[37,41,42,44]$ due to the assumptions made in this analysis and exclusion of revenue from non-traditional sources. For example, odor was considered a revenue source by The Minnesota Project report, in which T1-T5 designs were proposed, at an annual price of $18,000 \$$ for a 100 -cow system [44]. Due to the exclusion of odor and other differing assumptions, the revenues calculated in The Minnesota Project Report for $\mathrm{T} 1-\mathrm{T} 5$ were $50 \%$ greater than the revenues calculated in this study. State renewable energy credits can also be a source of revenue and were included in a cost analysis of D3 at an estimated annual value of $2000 \$$ [37]. Savings due to the reductions in spreading costs due to the exclusion of rainwater from a lagoon with covered digester were used in a previous cost analysis of D6, estimated at an annual saving rate of $4000 \$$ [42]. In all, the estimated revenue for D6 was $10,000 \$$ lower in this study compared to the previous study due to the exclusion of saving from rainwater reduction in the lagoon and greater savings from electricity and heat use [42].
Additional future revenue may come from innovative uses of the biogas effluent and digested fibers separated from the digestate. The use of compressed biogas as a substitute transportation fuel for gasoline and diesel is being investigated globally as governments aim to increase renewable energy use $[68,69]$. Biogas powered fuel cells are another technology being investigated [70]. Apple and Microsoft are both planning on powering future data centers with fuel cells run on biogas [71]. A potential revenue source from digestion by-products stems from the recovery of struvite (magnesium ammonium phosphate) from digester effluent for use as a commercial fertilizer. Struvite is being successfully recovered in Europe and Asia and on a pilot-scale basis in the U.S. [72,73]. Digested fiber has found use in the production of biodegradable plant pots and as a nursery media component to replace peat, coir and bark [74].

\subsection{Minimum herd size needed for economically viable digestion in the U.S.}

Our results suggest that anaerobic digestion can be economically viable under specific conditions for farms with herd sizes as low as 100 cows. However, these systems will be an additional expense to the farm as the capital and operating costs cannot be overcome by the revenue produced from small herds. Ten of the 16 systems had a net cost per cow of less than $100 \$$ per year, which could be considered a necessary business expense when odor control is required for continued operation.

The annual cost of $100 \$$ per cow could be overcome in multiple scenarios. The use of 50\% cost sharing makes six of the 16 systems cost effective without any additional revenue sources. Conversely, additional revenue of $100 \$$ per cow, or $10,000 \$$ per year for a 100-cow farm, from co-digestion of off-farm food waste or innovative uses of the biogas or digestate can make a digester cost effective without the need for additional cost sharing. The monthly tipping fees from off-farm waste of $1000 \$$ would make seven systems become cost effective.

AgSTAR bases its minimum herd size (500 cows) on an estimated capital cost of $1500 \$$ per cow for an aerobic digestion system [18]. Using the AgSTAR method for estimating capital costs for three types of digesters (plug-flow, complete mixed, and covered lagoon), only the complete mixed system, with average estimated costs of $1500 \$$ for $100-250$ cows, corresponded with the capital costs found in this analysis [18]. The AgSTAR plug-flow digester estimate (2200\$) was greater than the $1800 \$$ per cow averaged among the systems in this analysis and the AgSTAR covered lagoon estimate (3100\$) was roughly double the $1500 \$$ average among the systems analyzed.

\section{Conclusions}

Our results suggest that, with cost sharing, economically viable AD systems are possible on 250-cow dairies. Although no system had a positive cash flow under the assumed conditions $(8 \%$ discount rate, 20-year term), six of the 16 systems had positive cash flows when $50 \%$ cost sharing was included in the analysis. Additional revenue streams, such as tipping fees for food 
waste, or additional cost sharing will be necessary to have economically viable AD systems on 100-cow dairies.

\section{Acknowledgements}

This work was supported by funding from the Maryland Water Resources Research Center (Grant\# 06HQGR0090) and University of Maryland Agriculture Experiment Stations. We would like to thank Jon Leith, Mike Kemp, and Brad Green at the USDA Beltsville Agricultural Research Center for their support and assistance. We also wish to thank Gary Seibel and the ENST Project Development Center, as well as student assistants Faaiz Ajaz, Scott Allen, Grant Hughes-Baldwin, Ashley Belle, Anisha Gupta, Kayoko Iwata, Caiti Jackson, PJ Klavon, Sol Lisboa Kotlik, Akua Nkrumah, Ryan Novak, Owen Williams, and Freddy Witarsa.

\section{R E F E R E N C E S}

[1] Martin JH. A comparison of dairy manure management with and without anaerobic digestion and biogas utilization. Boston, MA: Eastern Research Group, Inc; 2004 Jun.. Contract no.: 68-W7-0068

[2] Pain BF, Misselbrook TH, Clarkson CR, Rees YJ. Odor and ammonia emissions following the spreading of anaerobically-digested pig slurry on grassland. Biol Waste 1990;34(3):259-67.

[3] Powers WJ, Van Horn HH, Wilkie AC, Wilcox CJ, Nordstedt RA. Effects of anaerobic digestion and additives to effluent or cattle feed on odor and odorant concentrations. J Anim Sci 1999;77(6):1412-21.

[4] Gerardi MH. The microbiology of anaerobic digesters. Hoboken, N.J.: Wiley-Interscience; 2003.

[5] Sahlstrom L. A review of survival of pathogenic bacteria in organic waste used in biogas plants. Bioresour Technol 2003;87(2):161-6.

[6] Lansing S, Botero RB, Martin JF. Waste treatment and biogas quality in small-scale agricultural digesters. Bioresour Technol 2008;99(13):5881-90.

[7] Lansing S, Martin JF, Botero RB, da Silva TN, da Silva ED. Wastewater transformations and fertilizer value when codigesting differing ratios of swine manure and used cooking grease in low-cost digesters. Biomass Bioenerg 2010;34(12):1711-20.

[8] Gloy BA. The potential supply of carbon dioxide offsets from the anaerobic digestion of dairy waste in the United States. Appl Econ Perspect Policy 2011;33(1):59-78.

[9] Lazarus WF, Rudstrom M. The economics of anaerobic digester operation on a Minnesota dairy farm. Rev Agr Econ 2007;29(2):349-64.

[10] Bishop CP, Shumway CR. The economics of dairy anaerobic digestion with coproduct marketing. Rev Agr Econ 2009;31(3):394-410.

[11] Chen Y, Yang GH, Sweeney S, Feng YZ. Household biogas use in rural China: a study of opportunities and constraints. Renew Sust Energ Rev 2010;14(1):545-9.

[12] Rao PV, Baral SS, Dey R, Mutnuri S. Biogas generation potential by anaerobic digestion for sustainable energy development in India. Renew Sust Energ Rev 2010;14(7):2086-94.

[13] US Environmental Protection Agency. Market opportunities for biogas recovery systems at U.S. livestock facilities.
Washington, DC: AgSTAR Program: USEPA, USDA, and DOE; 2010 Dec..

[14] Vanhorn HH, Wilkie AC, Powers WJ, Nordstedt RA. Components of dairy manure management systems. J Dairy Sci. 1994;77(7):2008-30.

[15] 2007 Census of agriculture. US Department of Agriculture, National Agricultural Statistics Service; 2009 Dec.. Report no.: AC-07-A-51.

[16] US Environmental Protection Agency. Market opportunities for biogas recovery systems: a guide to identifying candidates for on-farm and centralized systems. Washington, DC: AgSTAR Program: USEPA, USDA, and DOE; 2006. Report no.: EPA-430-8-06-004.

[17] Anaerobic digester database [internet]. Washington, DC: AgSTAR Program: USEPA, USDA, and DOE. Available from: http://www.epa.gov/agstar/projects/index.html [accessed 09.01.11].

[18] US Environmental Protection Agency. Anaerobic digestion capital costs for dairy farms. Washington, DC: AgSTAR Program: USEPA, USDA, and DOE; 2010.

[19] Metha A. The Economics and feasibility of electricity generation using manure digesters on small and mid-sized dairy farms. Madison, WI: University of Wisconsin Department of Agricultural and Applied Economics Energy Analysis and Policy Program; 2002.

[20] Moser MA. Is a digester right for your farm? [internet]. Available from: http://www.rcmdigesters.com/publications/ HoardsDairyman.pdf; 2005 Feb [accessed 07.01.11].

[21] Nelson C, Lamb J. Final report: Haubenschild farms anaerobic digester. St. Paul, MN: The Minnesota Project; 2002.

[22] Wright $\mathrm{P}$, Inglis S. An economic comparison of two anaerobic digestion systems on dairy farms. In: ASAE meeting paper no. 034154. ASAE Annual international meeting; July 27-30, 2003; Las Vegas, NV. St. Joseph MI: ASAE; 2003.

[23] Ghafoori E, Flynn PC. Optimizing the size of anaerobic digesters. Trans ASABE 2007;50(3):1029-36.

[24] Giesy R, Wilkie AC, de Vries A, Nordstedt RA. Economic feasibility of anaerobic digestion to produce electricity on Florida dairy farms. Gainesville, FL: University of Florida Institute of Food and Animal Science Extension; 2009. Publication no.: AN159.

[25] Gloy BA, Dressler JB. Financial barriers to the adoption of anaerobic digestion on US livestock operations. Agr Finance Rev 2010;70(2):157-68.

[26] Garrison AV, Richard TL. Methane and manure: feasibility analysis of price and policy alternatives. Trans ASAE 2005;48(3):1287-94.

[27] Bracmort K, Burns RT, Beddoes J, Lazarus W. An analysis of anaerobic digestion system costs on U.S. livestock production systems. In: ASAE meeting paper no. 084643. ASABE annual international meeting; June 29-July 2, 2008; Providence, RI. St. Joseph MI: ASABE; 2008.

[28] Yiridoe EK, Gordon R, Brown BB. Nonmarket cobenefits and economic feasibility of on-farm biogas energy production. Energ Policy 2009;37(3):1170-9.

[29] Lusk P. Methane recovery from animal manures the current opportunities casebook. Golden, CO: National Renewable Energy Laboratory; 1998. Report no.: 580-25145.

[30] Leuer ER, Hyde J, Richard TL. Investing in methane digester on Pennsylvania dairy farms: implication of scale economies and environmental programs. Agr Resour Econ Rev 2008;37(2):188-203.

[31] Wright P, Inglis S, Ma J, Gooch C, Aldrich B, Meister A, et al. Comparison of five anaerobic digestion systems on dairy farms. In: ASAE meeting paper no. 044032. ASAE/CSAE annual international meeting; August 1-4, 2004; Ottawa, ON. St. Joseph MI: ASAE; 2004. 
[32] Stokes JR, Rajagopalan RM, Stefanou SE. Investment in a methane digester: an application of capital budgeting and real options. Rev Agric Econ 2008;30(4):664-76.

[33] Final report: protocol for quantifying and reporting the performance of anaerobic digestion systems for livestock manures. Lexington, MA: Eastern Research Group Inc.; 2011 Mar..

[34] Meyer DJ, Lorimor JC. Field experiences with two Iowa plugflow digesters. In: ASAE meeting paper no. 034012. ASAE annual international meeting; July 27-30, 2003; Las Vegas, NV. St. Joseph MI: ASAE; 2003.

[35] Iowa Department of Natural Resources. Methane energy recovery on Iowa farms. Des Moines, IA: Iowa Department of Natural Resources; 2003.

[36] Schmidt D. Biogas and electrical production on the JerLindy farm. Prepared for The Minnesota Project; 2009.

[37] Lazarus WF. Economic analysis of the JerLindy farms anaerobic digester. Prepared for The Minnesota Project; 2009.

[38] Scruton D, Whitcomb O. Manure digesters for energy what's happening on Vermont farms? Alternative energy on the farm forum. Burlington, VT; Burlington, VT: University of Vermont Extension; May 4, 2005.

[39] BioProcessH2O, Inc. Final report: pilot project program North Williston cattle company. Portsmouth, RI: Prepared for Farm Pilot Project Coordination, Inc; 2008.

[40] Wright P, Ma J. Anaerobic digester at Freund dairy: case study. Ithaca, NY: Cornell University Manure Management Program; 2003. Report no.: case study AD-7.

[41] Wright P, Ma J. Fixed film digester at Farber dairy farm: case study. Ithaca, NY: Cornell University Manure Management Program; 2003. Report no.: case study AD-3.

[42] Wright P, Ma J. Anaerobic digester at Spring Valley dairy: case study. Ithaca, NY: Cornell University Manure Management Program; 2003. Report no.: case study AD-6.

[43] Coppinger E, Baylon D, Lenart J. Economic and operational experience of full-scale anaerobic dairy manure digester. Biogas and Alcohol Fuels Production 1980:220-33.

[44] Goodrich PR. Anaerobic digester systems for mid-sized dairy farms. St. Paul, MN: The Minnesota Project; 2005.

[45] Klavon KH. Design and economics of plug-flow, small-scale anaerobic digesters for temperate climates [thesis]. College Park, MD: University of Maryland; 2011.

[46] Beddoes JC, Bracmort KS, Burns RT, Lazarus WF. An analysis of energy production costs from anaerobic digestion systems on U.S. livestock production facilities. Washington, DC: US Department of Agriculture; 2007 Oct.

[47] Federal Reserve. Agricultural finance databook. Washington, DC: Division of Research and Statistics and Board of Governors of the Federal Reserve System; 2010 Jun. .

[48] Natural gas industrial prices. Washington, DC: US Department of Energy, Energy Information Administration; 2011 Sep..

[49] Annual energy review 2010. Washington, DC: US Department of Energy Information Administration; 2011 Oct.. Report no.: DOE/EIA-0384(2010).

[50] Lazarus W. Farm-based anaerobic digesters as an energy and odor control technology: background and policy issues. Washington, DC: US Department of Agriculture; 2008 Feb.. Report no.: 843 .

[51] Scruton D. Vermont's experience with the adoption of anaerobic digestion on farms. In: Conference proceedings from AgSTAR. AgSTAR national conference; November 28, 2007; Sacramento, CA. Washington, DC: AgSTAR; 2007.
[52] Database of State Incentives for Renewables \& Efficiency (DSIRE) [internet]. Raleigh, NC: North Carolina Solar Center. Available from: http://www.dsireusa.org [accessed 10.01.11].

[53] Weeks S. Anaerobic fixed-film digester system for dairy manure. In: NABEC meeting paper no. 03-023. Northeast agricultural \& biological engineering conference; August 2003; Storrs, CT. St. Joseph, MI: ASABE; 2003.

[54] Kramer J. Wisconsin agricultural biogas handbook. Madison, WI: Wisconsin Focus on Energy - Renewables Program; 2009 Dec..

[55] Gooch CA, Hogan JS, Glazier N, Noble R. Use of post-digested separated manure solids as freestall bedding: a case study. In: Proceedings of the National Mastitis Council; NMC 45th annual meeting; January 22-25. Tampa, FL. Verona, WI: National Mastitis Council; 2006. p. 151-60.

[56] Eggleston HS, Buendia L, Miwa K, Ngara T, Tanabe K. IPCC guidelines for national greenhouse gas inventories. Japan: National Greenhouse Gas Inventories Programme; 2006.

[57] Market info: historical data [internet]. Chicago, IL: Intercontinental Exchange, Inc. (CCX). Available from:: https://www.theice.com/ccx.jhtml [accessed 09.03.11].

[58] Grogan T. Construction cost index history (1918-2006). Eng News-Rec 2006;256(11):43.

[59] Construction economics. Eng News-Rec 2007;258/259(24/ 1):27-8.

[60] Construction economics. Eng News-Rec 2009;263(1):97-8.

[61] Construction economics. Eng News-Rec 2010;264(1):31-2.

[62] Construction economics. Eng News-Rec 2011;266(1):37-8.

[63] Cherosky P, Li Y, Mancl K. Manure to energy through anaerobic digestion. Columbus, $\mathrm{OH}$ : The Ohio State University Extension; 2011. Report no.: AEX-653.1-11.

[64] Key N, Sneeringer S. Climate change policy and the adoption of methane digesters on livestock operations. Washington, DC: US Department of Agriculture; 2011 Feb.. Report no.: 111.

[65] Powers CA, Schulte DD, Stowell RR. Carbon credits from livestock production. Lincoln, NE: University of NebraskaLincoln Extension; 2009. Report no.: G1962.

[66] US Department of Agriculture. Funding programs for developing anaerobic digestion systems. Washington, DC: AgSTAR Program: USEPA, USDA, and DOE; 2011.

[67] Scott N, Ma J. A guideline for co-digestion of food wastes in farm-based anaerobic digesters. Ithaca, NY: Cornell Cooperative Extension; 2004. Report no.: Fact Sheet FW-2.

[68] Sustainable Transport Solutions Ltd. Biogas as a road transport fuel: an assessment of the potential role of biogas as a renewable transport fuel. Brighton, England: National Society for Clean Air and Environmental Protection; 2006 Jun..

[69] Leonhardt E, Castillo A, Cruse R, Freund A, Iopin M, Parent S, et al. Final report: biomethane for transportation. Washington, DC: USEPA; 2007. EPA Grant no SU833269.

[70] Spiegel RJ, Preston JL. Test results for fuel cell operation on anaerobic digester gas. J Power Sources 2000;86(1):283-8.

[71] Anaerobic digest. BioCycle 2012;53(5):14.

[72] Westerman PW, Bowers KE, Zering KD. Phosphorus recovery from covered digester effluent with a continuous-flow struvite crystallizer. Appl. Eng. Agric. 2010;26(1):153-61.

[73] Hotaling J, Hamkins M. Final report: struvite recovery from digested dairy manure and regional manure anaerobic digestion study. Albany, NY: New York State Energy Research and Development Authority; 2006 Jun.. Report no.: 06-10.

[74] Alexander R. Digestate utilization in the US. BioCycle 2012;53(1):56. 